\title{
Some Properties of Luminal Sucrase and Sucrase-Isomaltase Complex in Rat Small Intestine
}

\author{
Masako ABE, ${ }^{1}$ Kazuhiko YAMAdA, ${ }^{1}$ Norimasa HosoyA, ${ }^{1}$ \\ and Sachiko MORIUCHI ${ }^{2}$ \\ ${ }^{1}$ Department of Nutrition, School of Health Sciences, \\ Faculty of Medicine, University of Tokyo, \\ Bunkyo-ku, Tokyo 113, Japan \\ ${ }^{2}$ Department of Food and Nutrition, School of Home Economics, \\ Japan Women's University, Bunkyo-ku, Tokyo 112, Japan
}

(Received August 14, 1984)

\begin{abstract}
Summary Some properties of luminal sucrase-isomaltase complex and the effect of luminal fluid on their complex were studied in rat small intestine. Luminal contents were collected by flushing the small intestine with the buffered solution. The enzyme activity was observed in luminal contents and intestinal mucosa. Sucrase and isomaltase activities were located mainly in the intestinal mucosa. However, approximately $20 \%$ of sucrase and $10 \%$ of isomaltase activities of total small intestine were found in the luminal contents. A significant amount of sucrase without isomaltase activity, the molecular weight of which was estimated at about 140,000 daltons, was found in the luminal supernatant of the distal intestine in addition to the complexed form of sucrase and isomaltase. The luminal sucrase and sucrase-isomaltase complex had similar properties such as $K_{\mathrm{m}}$ values, optimal $\mathrm{pH}$, molecular weights and antigenicity against anti sucrase-isomaltase antibody compared with brush border membranebound sucrase-isomaltase complex. Furthermore, the supernatant of the luminal contents of the ileum had a degradative effect on the isomaltase moiety of the purified sucrase-isomaltase complex and a free sucrase without isomaltase also appeared in vitro as observed in vivo. These results suggest that the sucrase-isomaltase complex is released into the intestinal lumen from the brush border membrane and that a luminal factor affects the degradation step of this enzyme as well as the biosynthesis of sucrase-isomaltase complex.
\end{abstract}

Key Words sucrase-isomaltase complex, luminal sucrase, intestinal luminal fluid

\footnotetext{
${ }^{1}$ 安部真佐子, 山田和彦, 細谷憲政, ${ }^{2}$ 森内幸子
} 
Among brush border hydrolases, which are involved in the terminal digestion of nutrients, sucrase and isomaltase have been isolated as an enzyme-enzyme complex from rabbit(1), human(2), pig(3), rat (4) and chick(5). Although the mechanism of the biosynthesis of sucrase-isomaltase complex has not been clearly established, the role of luminal pancreatic proteases expected to be of importance for the formation of the complex $(3,6,7)$.

Other intraluminal factors including food intake, bile secretion and microflora would also be important for the regulation of the activity of sucrase-isomaltase complex through the effect on the degradation of the enzymes $(8-10)$. Sucraseisomaltase complex is exposed to intestinal luminal fluid. Thus, it seems likely that the degradative turnover of the complex could be modulated by luminal factors.

However, little is known about the effect of these intraluminal factors on the activity of sucrase-isomaltase complex. Therefore, we examined the activity of sucrase and isomaltase in the luminal contents of the small intestine and observed the effect of luminal fluid on sucrase-isomaltase complex.

\section{METHODS}

Animals. Male Wistar rats, weighing approximately $250 \mathrm{~g}$, were used for the experiment. Water and standard laboratory chow (Oriental Yeast Co.) were given ad libitum. Rats were killed by decapitation between $9: 00$ and 10:30 h.

Preparation of luminal contents and mucosa from small intestine. The entire small intestine was removed and divided into three segments, viz. from pylorus to the ligaments of Treitz as duodenum and two equal lengths of jejunum and ileum. To separate luminal contents from the mucosa, each segment was flushed with $2 \mathrm{ml}$ (duodenum), $5 \mathrm{ml}$ (jejunum), or $10 \mathrm{ml}$ (ileum) of $10 \mathrm{~mm}$ potassium phosphate (KP)

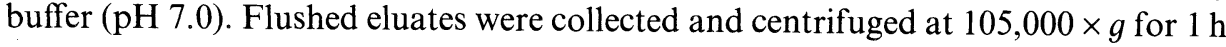
at $4{ }^{\circ} \mathrm{C}$. The supernatant and the suspension of precipitates homogenized with $10 \mathrm{~mm} \mathrm{KP}$ buffer ( $\mathrm{pH} 7.0$ ) were stored at $-20^{\circ} \mathrm{C}$ until used. After flushing, each intestinal segment was immediately cut open, rinsed and then blotted on filter paper. Intestinal mucosa, which was scraped off with a glass slide, was homogenized with 9 vol. of $10 \mathrm{~mm} \mathrm{KP}$ buffer ( $\mathrm{pH} 7.0$ ) and stored at $-20^{\circ} \mathrm{C}$ until used.

Solubilization of sucrase-isomatase complex from intestinal homogenate by papain treatment. Five milliliters of the mucosal homogenate was incubated with $1.6 \mathrm{mg}$ papain and $4.0 \mathrm{mg}$ cysteine- $\mathrm{HCl}$ for $90 \mathrm{~min}$ at $37^{\circ} \mathrm{C}$. After papain treatment, the incubation mixture was centrifuged at $105,000 \times g$ for $1 \mathrm{~h}$ at $4^{\circ} \mathrm{C}(11)$. Supernatant was used as a papain solubilized sucrase-isomaltase complex.

Sephadex G-200 column chromatography. Papain-solubilized sucraseisomaltase complex from intestinal mucosa and the supernatant of luminal contents was applied to a Sephadex G-200 column $(1.5 \times 30 \mathrm{~cm})$, equilibrated with $10 \mathrm{mM} \mathrm{KP}$ buffer ( $\mathrm{pH} 7.0$ ), and eluted with the same buffer in the cold room. Flow rate was $4.5 \mathrm{ml} / \mathrm{h}$. Three-milliliter fractions were collected and aliquots were used for the enzyme assay. 
Quantitative immunoprecipitation by antibody against sucrase-isomaltase complex. The immunoreactivity against anti sucrase-isomaltase complex antibody was determined in the fractions containing sucrase and isomaltase activities by immunoprecipitation described previously (12). The immunoglobulin fraction was collected by $35 \%$ saturation with ammonium sulfate from rabbit antiserum. After centrifugation, the precipitate was dissolved in sodium phosphate-buffered saline ( $\mathrm{pH}$ 7.4) and dialyzed against the same buffer for $18 \mathrm{~h}$. Excess immunogloblin, which precipitated purified sucrase-isomaltase complex completely, was incubated with the sample fractions in $0.15 \mathrm{ml}$ of sodium phosphate-buffered saline $(\mathrm{pH} 7.4)$ at $37^{\circ} \mathrm{C}$ for $60 \mathrm{~min}$ and then $4^{\circ} \mathrm{C}$ for $20 \mathrm{~h}$. After incubation, the mixture was centrifuged at $1,500 \times g$, for $30 \mathrm{~min}$ at $4^{\circ} \mathrm{C}$. Aliquots of the mixture before centrifugation and the supernatant were used for enzyme assay.

Polyacrylamide gel electrophoresis. Polyacrylamide gel electrophoresis of the eluates from Sephadex G-200 column chromatography was carried out according to the method of Davis $(6.0 \%$ in acrylamide, $\mathrm{pH} 9.4)(13)$. After the electrophoresis, the gels were either stained with $1 \%$ Coomassie brilliant blue or stained enzymatically for sucrase and isomaltase using sucrose and isomaltose as substrates according to the method of Faye(14). Molecular weight analysis of sucrase and sucraseisomaltase complex on polyacrylamide gel electrophoresis was carried out according to the method of Hedrick and Smith (15). For the molecular weight standardization of gel, thyroglobulin $(667,000)$, ferritin $(440,000)$, catalase $(232,000)$, lactate dehydrogenase $(140,000)$, and albumin $(67,000)$ were used.

Degradation of purified sucrase-isomaltase complex by ileal contents in vitro. The supernatant of the ileal contents was treated with sufficient immunoglobulin against sucrase-isomaltase complex to remove the intrinsic sucrase and isomaltase activities by immunoprecipitation. After centrifugation at $1,500 \times g$ for $30 \mathrm{~min}$, the supernatant was used for the degradation study of purified sucraseisomaltase complex. To one milliliter of sucrase-isomaltase complex in $10 \mathrm{~mm} \mathrm{KP}$ buffer ( $\mathrm{pH} 7.0$ ), $1 \mathrm{ml}$ of the ileal supernatant was added. After incubation at $37^{\circ} \mathrm{C}$, aliquots were used for the assay of enzyme activity and polyacrylamide gel electrophoresis.

Assay procedure. Disaccharidase activities were determined by the method of Dahlqvist (16). Substrate concentration was $28 \mathrm{~mm}$ in sucrose and maltose and $2.8 \mathrm{~mm}$ in isomaltose in $0.1 \mathrm{M}$ sodium maleate buffer ( $\mathrm{pH} 6.0$ ). Protein concentration was determined by the method of Lowry et al. using bovine serum albumin as a standard (17).

Chemicals. Papain, glucose oxidase and peroxidase were obtained from Sigma Co., Ltd. Acrylamide and 3,3'-diaminobenzidine tetrahydrochloride were purchased from Wako Chemical, Ltd. Glucose and sucrose were obtained from Kokusan Chemical Works, Ltd. Isomaltose and maltose were kindly provided by Hayashibara Co., Ltd. Standard marker proteins used for the determination of molecular weight were the products of Pharmacia Fine Chemical Co., Ltd. Other chemicals used were of reagent grade. 


\section{RESULTS}

The distribution of sucrase and isomaltase activities in intestinal mucosa and luminal contents along the small intestine

In good agreement with other investigators $(18,19)$, sucrase and isomaltase activities were located mainly in jejunal and ileal mucosa. They are expressed as total activities, viz. activities per segment. However, approximately $20 \%$ of sucrase and $10 \%$ of isomaltase activities out of those of the entire small intestine were found in the luminal contents (Table 1). In contrast to mucosal activities, the amount of luminal activity increased in the distal part of the intestine. The supernatant of luminal contents of the ileum contained larger amounts of both sucrase and isomaltase activities, viz. $25 \%$ of total ileal sucrase activity and $13 \%$ of isomaltase activity. A significant increase in the activity ratio of sucrase to isomaltase was observed in the luminal supernatant of the ileum compared with the activity ratio of the ileal mucosa.

Sephadex G-200 column chromatography of sucrase and isomaltase activities in intestinal mucosa and luminal contents

It is known that the sucrase-isomaltase complex is retained by Sephadex G-200 owing to a substrate-enzyme like interaction involving its isomaltase site(1). Therefore, in order to determine whether the increases of the activity ratio of sucrase and isomaltase in the luminal contents accompany the changes in the properties of sucrase-isomaltase complex, the chromatographic behavior of the luminal sucrase and isomaltase on Sephadex G-200 column were observed and compared with that of papain-solubilized fractions from intestinal mucosa.

Table 1. Total activities of sucrase and isomaltase in intestinal mucosa and luminal contents.

\begin{tabular}{|c|c|c|c|c|c|c|}
\hline & \multicolumn{3}{|c|}{ Sucrase } & \multicolumn{3}{|c|}{ Isomaltase } \\
\hline & \multirow{2}{*}{ Mucosa } & \multicolumn{2}{|c|}{ Contents } & \multirow{2}{*}{ Mucosa } & \multicolumn{2}{|c|}{ Contents } \\
\hline & & Supernatant & Precipitate & & Supernatant & Precipitate \\
\hline Duodenum & $\begin{array}{c}114 \pm 12 \\
(97.6 \pm 0.8)\end{array}$ & $\begin{array}{c}1 \pm 0.1 \\
(0.5 \pm 0.1)\end{array}$ & $\begin{array}{c}2 \pm 0.8 \\
(1.9 \pm 0.7)\end{array}$ & $\begin{array}{c}54 \pm 5 \\
(98.0 \pm 0.6)\end{array}$ & $\begin{array}{c}0 \\
(0)\end{array}$ & $\begin{array}{c}1 \pm 0.4 \\
(1.9 \pm 0.6)\end{array}$ \\
\hline Jejunum & $\begin{array}{l}1,240 \pm 49 \\
(93.9 \pm 0.7)\end{array}$ & $\begin{array}{c}41 \pm 7 \\
(2.9 \pm 0.5)\end{array}$ & $\begin{array}{c}55 \pm 16 \\
(3.2 \pm 0.8)\end{array}$ & $\begin{array}{c}745 \pm 37 \\
(96.3 \pm 1.5)\end{array}$ & $\begin{array}{c}18 \pm 3 \\
(2.1 \pm 0.5)\end{array}$ & $\begin{array}{c}6 \pm 2 \\
(0.5 \pm 0.2)\end{array}$ \\
\hline Ileum & $\begin{array}{c}496 \pm 46 \\
(60.3 \pm 2.4)\end{array}$ & $\begin{array}{c}199 \pm 12 \\
(24.5 \pm 1.0)\end{array}$ & $\begin{array}{c}106 \pm 13 \\
(15.2 \pm 0.9)\end{array}$ & $\begin{array}{c}295 \pm 22 \\
(75.7 \pm 1.0)\end{array}$ & $\begin{array}{c}52 \pm 4 \\
(13.4 \pm 0.6)\end{array}$ & $\begin{array}{c}42 \pm 4 \\
(10.9 \pm 0.6)\end{array}$ \\
\hline
\end{tabular}

( ): percent of combined activities in mucosa and luminal contents. Values are given Means $\pm \mathrm{SE}$ of 5 animals. Enzyme activities are expressed as $\mu \mathrm{mol}$ substrate hydrolyzed/mg protein $/ \mathrm{h}$. 


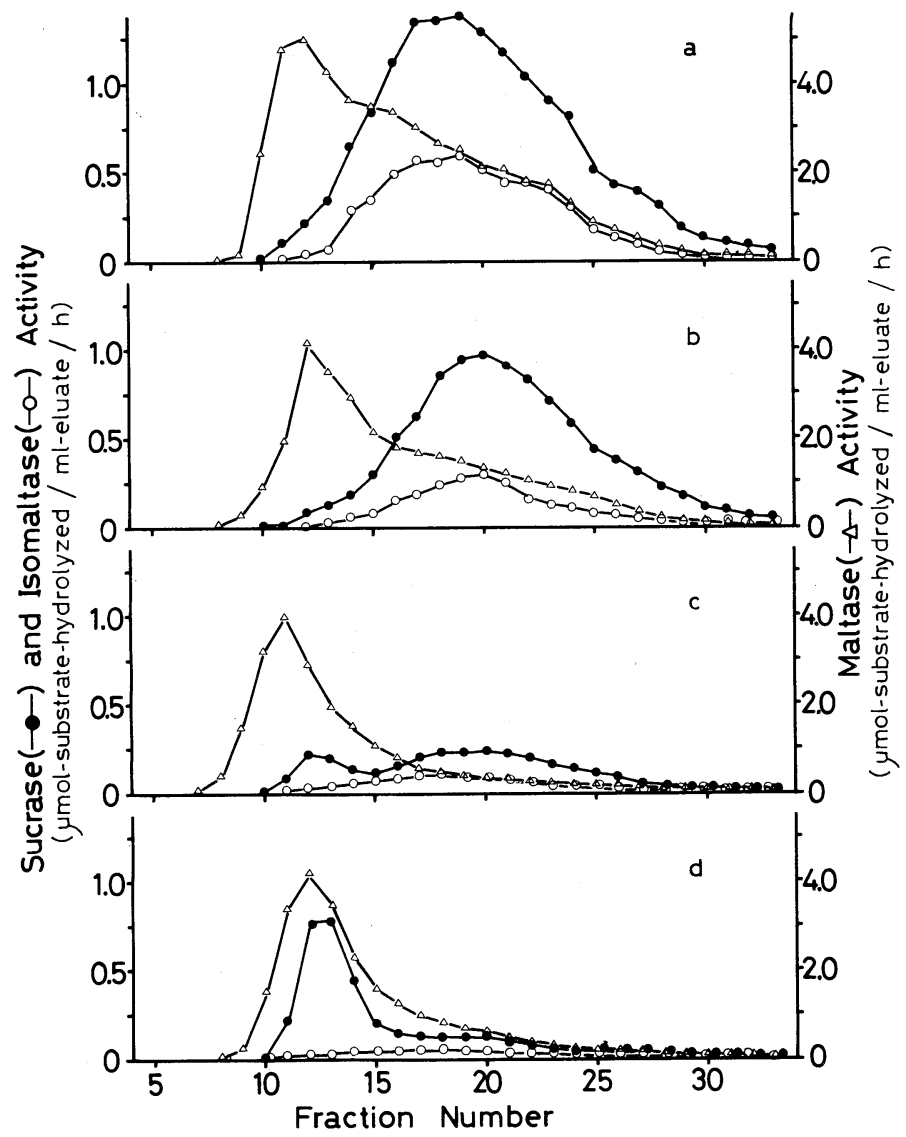

Fig. 1. Sephadex G-200 column chromatography of disaccharidases solubilized by papain from mucosa and supernatant of luminal contents of rat intestine. a, jejunal mucosa; b, ileal mucosa; $c$, jejunal contents, $d$, ileal contents.

As shown in Fig. 1, chromatographic profiles of mucosal disaccharidases showed that the main maltase activities were excluded at the void volume of the column, while sucrase and isomaltase activities were retained on Sephadex and eluted only at the total volume of the column, in good agreement with our previous results $(11,12)$. Interestingly, a significant amount of sucrase activity was detected at the void volume of the column in the supernatant of the luminal contents both in jejunum and ileum. In the ileum, this void volume peak of sucrase increased concomitantly with the decrease of sucrase-isomaltase complex.

On the other hand, the activity ratio of sucrase to isomaltase in the fractions of the sucrase-isomaltase complex of intestinal mucosa on Sephadex column was nearly the same as that of the luminal contents.

These results suggest that free sucrase, which does not form a complex with 
isomaltase, is present in the luminal contents, especially in the distal part of the intestine.

Some properties of mucosal and luminal sucrase-isomaltase complex and luminal sucrase

To characterize the sucrase and isomaltase further, Michaelis constants $\left(K_{\mathrm{m}}\right)$, $\mathrm{pH}$ for optimal activities and molecular weights were observed in the sucrase fraction (peak I) on Sephadex column chromatography of luminal contents and in the sucrase-isomaltase complex fraction (peak II) of mucosal and luminal contents (Table 2).

$K_{\mathrm{m}}$ values were 16 to $18 \mathrm{~mm}$ for sucrase activity and 3 to $4 \mathrm{~mm}$ for isomaltase activity, and there was no significant difference between intestinal mucosa and luminal contents. The optimal $\mathrm{pH}$ for all the enzymes was 6.0. According to enzymatic staining after electrophoresis, the molecular weights determined for sucrase and isomaltase in peak II were estimated as about 290,000 daltons in both mucosal and luminal fractions. The sucrase without isomaltase activity in peak I had a molecular weight estimated at about 140,000 daltons, almost half that of the sucrase-isomaltase complex.

In order to determine whether luminal sucrase and isomaltase were derived from the brush border membrane, their antigenicity against antibody of sucraseisomaltase complex purified from rat intestine was examined. As shown in Table 3, both the sucrase and isomaltase activities in the supernatants of jejunal and ileal contents were almost completely precipitated with excess antibody. Furthermore, sucrase in peak I of the ileal contents as well as sucrase-isomaltase complex in peak II of the intestinal mucosa showed antigenicity against antibody to sucraseisomaltase complex.

These results clearly showed that the sucrase and isomaltase activities in luminal contents were derived from the intestinal mucosa.

Table 2. Comparison of mucosal sucrase-isomaltase complex and luminal sucraseisomaltase complex and sucrase.

\begin{tabular}{|c|c|c|c|c|c|c|}
\hline & & \multicolumn{2}{|c|}{$\begin{array}{c}\text { Michaelis } \\
\text { constant (mM) }\end{array}$} & \multicolumn{2}{|c|}{ Optimal pH } & \multirow{2}{*}{$\begin{array}{c}\text { Molecular } \\
\text { weight }\end{array}$} \\
\hline & & $\mathrm{S}$ & I & $\mathrm{S}$ & I & \\
\hline Peak I & Ileal content & 17.9 & - & 6.0 & - & 140,000 \\
\hline \multirow{3}{*}{ Peak II } & Mucosa & 16.3 & 3.00 & 6.0 & 6.0 & 279,000 \\
\hline & Jejunal content & 17.9 & 3.55 & 6.0 & 6.0 & 295,000 \\
\hline & Ileal content & 17.5 & 3.82 & 6.0 & 6.0 & 295,000 \\
\hline
\end{tabular}

$\mathrm{S}$, sucrase; I, isomaltase. 
Table 3. Precipitation of sucrase and isomaltase in the intestinal mucosa, the supernatant of luminal contents and its eluates from Sephadex G-200 column chromatography.

\begin{tabular}{lcc}
\hline & Sucrase & Isomaltase \\
\hline Supernatant of jejunal contents & $3.1 \pm 1.1^{\mathrm{a}}$ & $1.3 \pm 0.7^{\mathrm{a}}$ \\
Supernatant of ileal contents & $1.8 \pm 0.3^{\mathrm{a}}$ & $1.6 \pm 0.6^{\mathrm{a}}$ \\
\hline Peak I Ileal contents & $2.5 \pm 0.9^{\mathrm{a}}$ & - \\
Peak II Mucosa & n.d. & n.d. \\
Jejunal contents & $2.0 \pm 0.8^{\mathrm{a}}$ & n.d. \\
Ileal contents & $1.2 \pm 0.5^{\mathrm{a}}$ & n.d. \\
\hline
\end{tabular}

-, not determined; n.d., not detectable. ${ }^{a}$ Means \pm SE of 5 animals. Values are expressed as the percent of remained activity in the supernatant after centrifugation with antisucrase-isomaltase antibody.

(a)

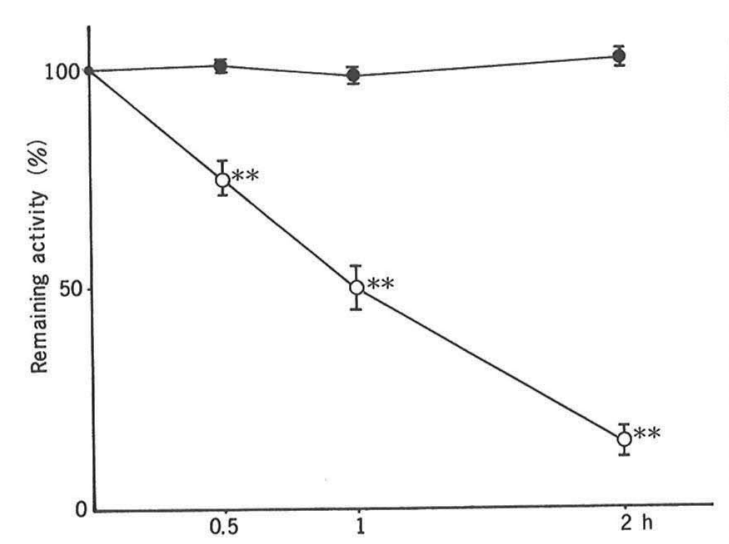

(b)

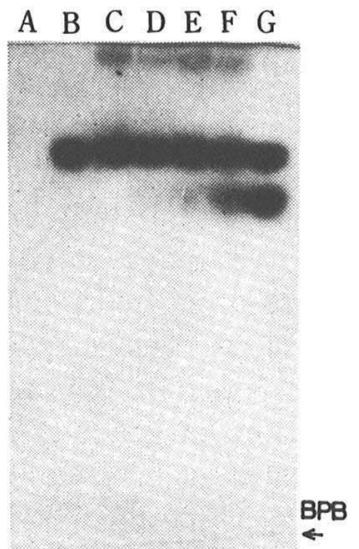

Fig. 2. Effect of ileal contents on purified sucrase-isomaltase complex in vitro. a. Time course of the degradation of purified sucrase-isomaltase complex by ileal contents. o, sucrase activity; $O$, isomaltase activity. Each point represents mean $\pm \mathrm{SE}$ of 5 animals. **Significantly different from 0 -time at $p<0.005$. b. Electrophoretic patterns stained by sucrase activity. Lane A: Supernatant of ileal contents absorbed by antisucrase-isomaltase IgG. Lane B: Purified sucrase-isomaltase complex. Lane C-F: 0, 0.5, 1 and $2 \mathrm{~h}$ after incubation with A and B. Lane G: Supernatant of ileal contents. BPB: Tracking dye, bromophenol blue.

Effect of luminal contents on purified sucrase-isomaltase complex from intestinal mucosa

Isomaltase activity in the luminal contents of ileum was rather low compared with sucrase activity, and larger amounts of sucrase without isomaltase activity were found in the ileal contents. Therefore, the supernatants of ileal contents had Vol. 31, No. 2, 1985 
sucrase and isomaltase removed by absorption with antibody, and the effect of the ileal contents on purified sucrase-isomaltase complex was observed.

Sucrase activity was not affected by incubation with luminal contents at $37^{\circ} \mathrm{C}$ up to $2 \mathrm{~h}$. However, isomaltase activity was significantly decreased within $0.5 \mathrm{~h}$, and thereafter, $80 \%$ of isomaltase activity disappeared during the following $2 \mathrm{~h}$ (Fig. 2a). These effects were not observed in the incubation at $0^{\circ} \mathrm{C}$ (data not shown). Figure $2 \mathrm{~b}$ shows the result of enzymatic staining for sucrase activity after the electrophoresis of the samples treated with luminal contents. Only the sucrase-isomaltase complex of 290,000 daltons was observed at time 0 . However, a second activity of sucrase with a molecular weight of 140,000 daltons, the electrophoretic mobility of which was the same as that of free sucrase in the luminal contents of the ileum, became visible after 1 and $2 \mathrm{~h}$ of incubation.

\section{DISCUSSION}

The intestinal epithelial cells are constantly renewed by mitotic division of crypt cells. They migrate to the villus and are released from the tip of the villus into the lumen $(20,21)$. The intestinal brush border proteins have also been shown to have a rapid turnover (22). Previous studies suggested that the rapid turnover of the digestive enzymes in the brush border membrane involved in extracellular degradation into the luminal side as well as in intracellular degradation $(9,18,19,23)$.

In the present study, it was clearly shown that large sucrase and isomaltase activities were found in the luminal contents of rat intestine. These enzymes were soluble and originated from the brush border membrane according to the kinetics observed and antigenicity against anti sucrase-isomaltase antibody. Alpers and Tedesco reported that surface enzymes of enterocytes were partly removed from the membrane by the action of pancreatic proteases such as elastase (23). Vasseur et al. demonstrated the release of brush border enzymes by deoxycholate in vivo using rat intestine (9). Olsen and Korsmo reported that bacterial enzymes were not involved to any significant extent in the turnover of surface enzymes (24). It was also shown that pancreatic duct ligation caused a significant increase of disaccharidase activity in the intestinal mucosa (25). These results suggest that digestive hydrolases could be modulated by luminal factors. Sucrase and isomaltase are biosynthesized as a single chain polypeptide, localized on the luminal side of the brush border membrane and subsequently cleaved into mature subunits by pancreatic proteases $(3,6)$. Therefore the regulation of sucrase and isomaltase activity are strongly affected by the luminal factors of the intestine.

We observed activity of sucrase, which did not form a complex with isomaltase, in the supernatant of jejunal and ileal contents. This sucrase, with an apparent molecular weight of 140,000 daltons, was formed more in the ileal contents. We examined the effect of luminal contents of the ileum on the sucrase-isomaltase complex purified from rat small intestine in vitro. A significant amount of sucrase without isomaltase activity was produced from the purified sucrase-isomaltase 
complex during the treatment of ileal contents. Moreover, the effect of luminal contents was temperature dependent. These results suggest that sucrase-isomaltase complex is released into the intestinal lumen from the brush border membranes and that isomaltase is degraded rapidly by some luminal factors. However, it is an open question whether the degradation of isomaltase occurs in the membrane-bound form of sucrase-isomaltase complex.

There could be many factors involved in the regulation of enzyme activities in the brush border membrane, such as diet composition, microorganisms, gastrointestinal hormones, bile acid and so on. Although further studies will be needed to elucidate the mechanism of the regulation of brush border hydrolases, we can speculate, at present, that some luminal factors affect the step of degradation of sucrase-isomaltase complex as well as the step of maturation into the two subunit form of sucrase-isomaltase complex.

\section{REFERENCES}

1) Kolinska, J., and Semenza, G. (1967): Studies on intestinal sucrase and on intestinal sugar transport. V. Isolation and properties of sucrase-isomaltase from rabbit small intestine. Biochim. Biophys. Acta, 146, 181-195.

2) Conklin, K. A., Yamashiro, K. M., and Gray, G. H. (1975): Human intestinal sucraseisomaltase; identification of free sucrase and isomaltase and cleavage of the hybrid into active distinct subunits. J. Biol. Chem., 250, 5735-5741.

3) Sjöström, H., Noren, O., Christiansen, L. A., Wacker, H., and Semenza, G. (1980): A fully active, two-active-site, single-chain sucrase-isomaltase from pig small intestine, implications for the biosynthesis of a mammalian integral stalked membrane protein. $J$. Biol. Chem., 255, 11332-11338.

4) Sasaki, M., Yamada, K., Moriuchi, S., and Hosoya, N. (1979): Purification and characterization of rat intestinal sucrase-isomaltase complex. Eiyo to Shokuryo (J. Jpn. Soc. Food and Nutr.), 32, 201-208.

5) Mizuno, K., Moriuchi, S., and Hosoya, N. (1982): Demonstration of sucraseisomaltase complex in chick intestine. J. Nutr. Sci. Vitaminol., 28, 599-608.

6) Hauri, H., Wacker, H., Rickli, E., Bigler-Meier, B., Quaroni, A., and Semenza, G. (1982): Biosynthesis of sucrase-isomaltase. Purification and $\mathrm{NH}_{2}$-terminal amino acid sequence of the rat sucrase-isomaltase precursor (pro-sucrase-isomaltase) from fetal intestinal transplants. J. Biol. Chem., 257, 4522-4528.

7) Hauri, H., Quaroni, A., and Isselbacher, K. J. (1979): Biogenesis of intestinal plasma membrane posttranslational route and cleavage of sucrase-isomaltase. Proc. Natl. Acad. Sci. USA., 76, 5183-5186.

8) Riepe, S.P., Goldstein, J., and Alper, D.H. (1980): Effect of secreted bacteroides proteases on human intestinal brush border hydrolases. J. Clin. Invest., 60, 314-322.

9) Vasseur, M., Ferard, G., and Pousse, A. (1978): Rat intestinal brush border enzymes release by deoxycholate in vivo. Pflügers Arch., 373, 133-137.

10) Lorenzsonn, V., and Olsen, W. A. (1982): In vivo responses of rat intestinal epithelium to intraluminal dietary lectins. Gastroenterology, 82, 838-848.

11) Yamada, K., Moriuchi, S., and Hosoya, N. (1978): Developmental changes in the sucrase-isomaltase complex in the rat intestinal mucosa. J. Nutr. Sci. Vitaminol., 24, $177-184$.

Vol. 31, No. 2, 1985 
12) Yamada, K., Moriuchi, S., and Hosoya, N. (1979): Some characteristics of early appearing isomaltase in intestinal mucosa of suckling rat. J. Nutr. Sci. Vitaminol., 25, 543-552.

13) Davis, B. J. (1964): Disc electrophoresis-II. Method and application to human serum proteins. Ann. N. Y. Acad. Sci., 121, 404-427.

14) Faye, L. (1981): A new enzymatic staining method for the detection of radish $\beta$ fructosidase in gel electrophoresis. Anal. Biochem., 112, 90-95.

15) Hedrick, J. L., and Smith, A. J. (1968): Size and charge isomer separation and estimation of molecular weights of proteins by disc gel electrophoresis. Arch. Biochem. Biophys., 126, 155-164.

16) Dahlqvist, A. (1964): Method for assay of intestinal disaccharidases. Anal. Biochem., 7, $18-25$.

17) Lowry, O.H., Rosebrough, N.J., Farr, A. L., and Randall, R.J. (1951): Protein measurement with the folin phenol reagent. J. Biol. Chem., 193, 265-275.

18) Berteloot, A., Chabot, J.G., and Hugon, J.S. (1981): Turnover of mouse intestinal brush border membrane proteins and enzymes in organ culture. A direct evaluation from studies on the evaluation of enzyme activities during the culture. Biochim. Biophys. Acta, 678, 423-436.

19) Aramayo, L. A., de Silvia, D. G. H., Hughes, C. A., Brown, G. A., and Mcneish, A.S. (1983): Disaccharidase activities in jejunal fluid. Arch. Disease Childhood, 58, 686-691.

20) Leblond, C. P., and Stevens, C. E. (1948): The constant renewal of intestinal epithelium in the albino rat. Anat. Rec., 100, 357-377.

21) Quastler, H., and Sherman, F. G. (1959): Cell population kinetics in the intestinal epithelium of the mouse. Exp. Cell. Res., 17, 420-438.

22) Alpers, D.H. (1972): The relation of size to the relation rates of degradation of intestinal brush border proteins. J. Clin. Invest., 51, 2621-2630.

23) Alpers, D. H., and Tedesco, F. J. (1975): The possible role of pancreatic proteases in the turnover of intestinal brush border proteins. Biochim. Biophys. Acta, 401, 28-40.

24) Olsen, W. A., and Korsmo, H. A. (1982): Sucrase metabolism in germfree rats. Am. J. Physiol., 242, G650-G653.

25) Senegas-Balas, F., Balas, D., and Ribet, A. (1981): Effect of pancreatic duct ligation on the hamster intestinal mucosa. Variation of several hydrolases. Digestion, 21, 83-91. 